\title{
Assessment of land-use and land-cover changes in Pangari watershed area (MS), India, based on the remote sensing and GIS techniques
}

\author{
Chaitanya B. Pande ${ }^{1,2}$ (D) Kanak N. Moharir $^{2}$. S. F. R. Khadri ${ }^{2}$
}

Received: 16 October 2020 / Accepted: 4 May 2021 / Published online: 24 May 2021

(c) The Author(s) 2021

\begin{abstract}
In this paper, we focus on the assessment of land-use and land-cover change detection mapping to the effective planning and management policies of environment, land-use policy and hydrological system in the study area. In this study the soil and water conservation project has been applied during the five years and after five years what changes have been found in the land-use and land-cover classes and vegetation. In this view, this land-use and land-cover mapping is a more important role to decide the policy for watershed planning and management project in the semiarid region. In an emerging countries, fast industrialization and urbanization impose a significant threat to the natural atmosphere. The remote sensing and GIS techniques are crucial roles in the study of land-use and land-cover mapping during the years of 2007, 2014, and 2017. The main objective of this is to prepare the land-use and NDVI maps in the years of 2008, 2014 and 2017; these maps have prepared from satellite data using the supervised classification method. A normalized difference vegetation index map (NDVI) was done by using Landsat 8 and LISS-III satellite data. NDVI values play a major role in monitoring the vegetation and variation in land-use and land-cover classes. In these maps, four types of land are divided into four classes as agriculture, built-up, wasteland, and water body. The results of study show that agriculture land of $18.71 \%$ (158.24 Ha), built-up land of $0.62 \%(5.31 \mathrm{Ha})$, wasteland of $40.33 \%(341.02 \mathrm{Ha})$, and water body land of $17.39 \%$ (147 Ha) are increased. Land-use and land-cover maps and NDVI values show that agriculture land of $22.97 \%(194.29 \mathrm{Ha}), 5.46 \%(14.59 \mathrm{Ha})$, and $0.08 \%$ $(0.22 \mathrm{Ha})$ decreases during the years of 2008,2014 , and 2017 . The results directly indicate that the supervised classification method has been the accurate identified feature in the land-use map classes. This classification method has been given the better accuracy (95\%) from spatiotemporal satellite data. The accuracy was also tally with ground-truth and Google earth information. These results can be a very useful for the land-use policy, watershed planning, and management with natural resources, animals, and ecological systems.
\end{abstract}

Keywords Geospatial $\cdot$ RS $\cdot$ GIS $\cdot$ Satellite data $\cdot$ NDVI

\section{Introduction}

In the earth, environment and atmosphere are very sensitivity systems, but the system has been damaged due to various activities by natural and human with one more factor being climate change (Coppin et al. 2004). Land-use and landcover changes are directly distrusting the natural resources and ecological system balance (Verburg et al. 2004). The

Chaitanya B. Pande

chaitanay45@gmail.com

1 All India Coordinated Research Centre for Dryland Agriculture, Dr. PDKV, Akola, India

2 Department of Geology, Sant Gadge Baba Amravati University, Amravati, India study of LULC features such as forestry, wasteland, agriculture lands to wasteland and water body areas rise the resistant of the Earth surface area; these classes have changed the hydrological system, which raise the amount of earth surface runoff and decrease the replacement of groundwater (Caselles and Lopez Garcia 1989; Moscrip and Montgomery 1997). The land-use change classes are being regularly impacted on the ecological, cultivated and biodiversity land, particularly in the dry regions. For example, the LULC monitoring variations have been found due to village-level planning and micro-watershed development, LULC is regularly changed in the land-use and land-cover classes, and all these changes have effect on the surface runoff, decreased groundwater level, water and soil pollutants (Aydinoglu and Gungor 2010 and Pande and Moharir 2014). Thus, the changes of 
LULC pattern have been considered to effect on the groundwater quality contents and climate parameters (Osborne and Wiley 1988; Basnyat et al. 1999; Roth et al. 1996; Chapin et al. 2000, Lu et al. 2004 and Vijith and Satheesh 2007).

Land-use class is a most important to a new inventory regarding the past and current natural resources. These past and current data can be more useful to researchers, land-use policy, and societies (Suresh et al. 2011). The changes of land-use patterns were based on natural and socioeconomic issues driving the strength. These changes are day by day increasing the population rate since the large population has been leading to increase the pressure on the environmental, sustainable practices, and planning of the urban area, agricultural land. One of the major factors is drinking freshwater sources, which those factors subsequently contribute to changes of land-use and land-cover classes and pattern (Pande 2020a and 2020b). Mishra 2017 investigated the runoff and soil loss under various land-use practices through remote sensing and GIS technology, and this study has been helpful to the development of the Himalayan Watershed, India. Hua 2017 studied on the land-use and land-cover change detection impact on the water quality using remote sensing and multivariate statistics analysis.

Satellite technologies have been a more significant role in the geographic mapping, analysis of datasets, storing, capturing, and integrated database; hence, this technology is very important to display the natural resources and ecological information of past and present (Chilar 2000; Donnay et al. 2001; Chan et al. 2001; Selcuk et al. 2003; Lo and Choi 2004; Rogan and Chen 2004; Chander et al. 2009; Fichera et al. 2012; Ceccarelli et al. 2014; Chaitanya Pande 2014; El Bastawesy 2014). Nowadays, so many researchers and scientists studied the land-use and land-cover changes and more significant things that cultivated the land shifted to waste and other lands due to drought situations in the globe surface. Hence, the satellite data and decision-maker software tools should be needed to analysis, report, and regularly monitoring issues related to the ecosystem, water, soil and eco-friendly development, and planning (Hassan 2015). Mona Allam et al. (2018) studied on the land-use and land-cover variation and analysis based on the MLC and NDVI techniques and landsat satellite data in the semiarid and arid regions. Geospatial technologies are more effective technologies for regularly checking the multitemporal classification of variations in the land-cover and land-use classes (Kachhwala 1985; Brondizio et al. 1994; Jensen 2005; Bakr et al. 2010; Ahmad and Quegan 2012). RS and GIS technology have been given a chance to complete the insights like the spatiotemporal data of land-use maps. Those technologies have been globally approved for accurate judgement by scientific society (Prasad et al. 2018; Mishra et al. 2020). Accuracy data and changes of land-cover classes are found by ENVI and ARC-GIS software (Mohammady et al.
2015). As a substance of reality, the ground data were used as an information engine for grouping the signature samples' pixel numbers in satellite images and processed through supervised classification tools (Iqbal and Khan 2014). The important objective of this paper was to enclose the land-use parameters that contribute to the conversion of every landuse class and measure the changes during years of 2008 , 2014, and 2017 in the Pangari watershed area.

\section{Objective}

(1) To identify of LULC classes and classify using classification methods and satellite images.

(2) To prepare the NDVI and LULC maps for change detection analysis during 2007, 2014, and 2017 years.

(3) To assess the accuracy of LULC classes to understand the error matrix in mapping.

(4) The result of study can be useful to watershed development and land-use policy in the watershed area.

\section{Study area}

The Pangari watershed is located in Tq. Mehakar of Buldhana Districts in Maharashtra of India, which lies between $20^{\circ} 4^{\prime} 00^{\prime \prime} \mathrm{N}$ latitude and $76^{\circ} 6^{\prime} 00^{\prime \prime} \mathrm{E}$ longitude. The climate of the watershed is humid in the subtropical region. However, coldest months are October to January of the watershed area; the winter seasons of minimum and maximum temperatures were found between 8 to $15^{\circ} \mathrm{C}$, respectively. The watershed area is under the dry land agriculture zone so the total agriculture land depends on the rainwater and groundwater. So, particular agriculture crops are affected and decrease the crop yield production. Hence, land-use change is a very important to the development of hydrological process system and agriculture perspective (Fig. 1). Total annual rainfall is 750 to $900 \mathrm{~mm}$ by Dr. PDKV, Akola. The area is situated nearby forest and hilly regions. It is a very critical issues that have been facing LULC in the semiarid region. The clay, gravelly, and sandy soils were observed in the watershed area. The soybean, cotton, sorghum, chickpea, and wheat crops are found in the watershed area. The watershed area farmers are much more familiar with rainfed crops. The waterbody, agriculture, and other vegetation, built-up land, and wasteland area are most important to sustainable development and conserve the natural resources.

\section{Material and methods}

LULC classes are classified from satellite images by classification methods. LISS-III and Landsat 8 satellite images with a spatial resolution of $23.5 \mathrm{~m}$ and $30 \mathrm{~m}$ during the years of 2008, 2014, and 2017 were collected by Bhuvan web-based 


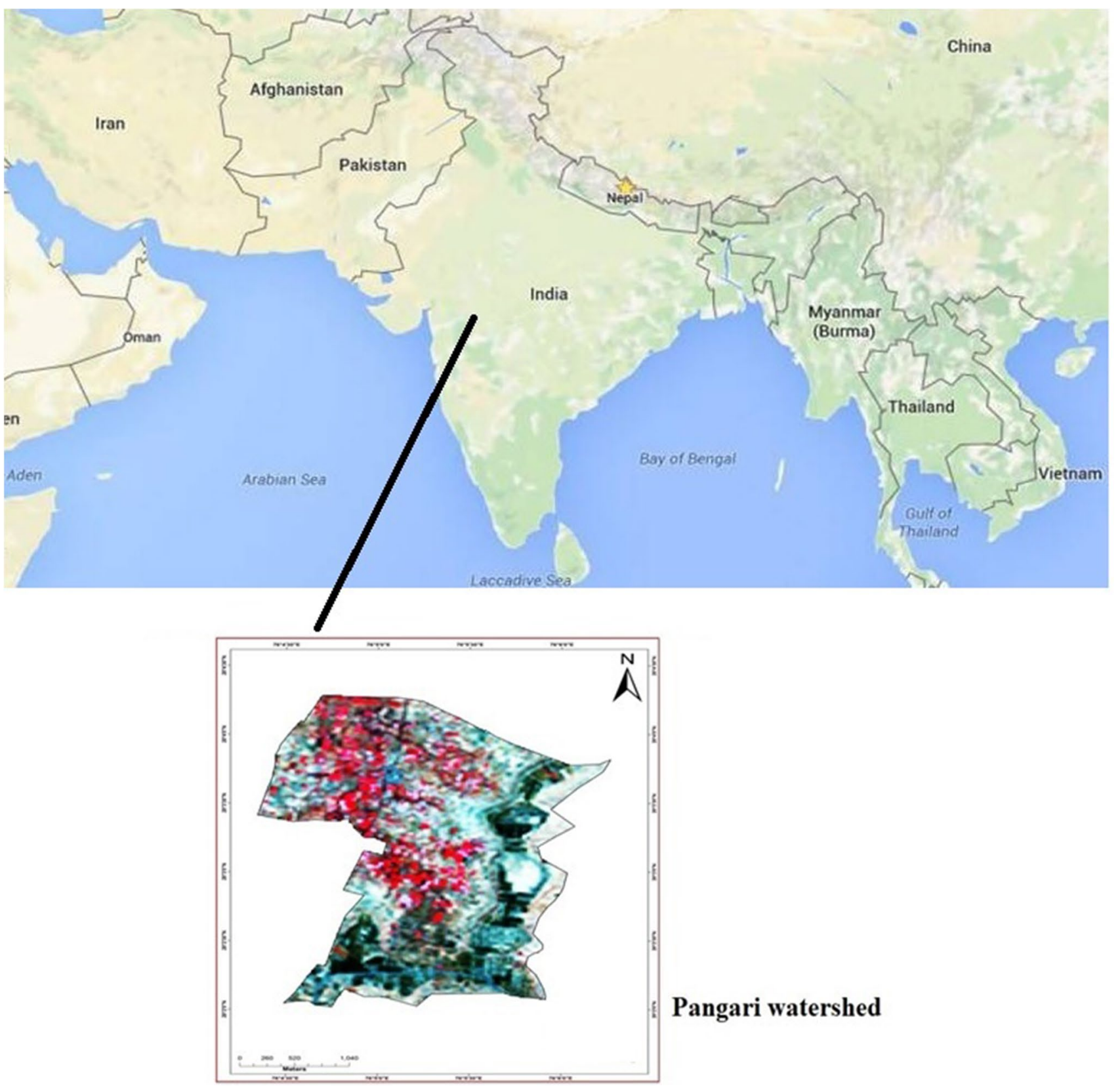

Fig.1 Location map of Pangari watershed

portals and Earth Explorer sites. These satellite images were calculated by assigning per-pixel signs and dividing the area into four classes on the bases of the specific digital number (DN) values of changed landscape elements. The three years of land-use and land-cover maps were prepared by Arc-GIS
10.3 software. LULC classification methods were done by using the supervised classification method (Table 1). The land-use and land-cover maps were cross-verified with the ground-truth information with high-resolution images. The five classes were classified such as water body, agriculture,
Table 1 Satellite data specifications

\begin{tabular}{|c|c|c|c|c|}
\hline Data & Year of acquisition & Bands/colour & Resolution(m) & Source \\
\hline IRS-LISS-III & 2008 & Multispectral & 23.5 & www.bhuvan.in \\
\hline Landsat $\mathrm{ETM}^{+}$ & 2014 and 2017 & Multispectral & 30 & www.earthexplore.com \\
\hline
\end{tabular}


Table 2 Details of land-cover results during years of 2008, 2014, and 2017

\begin{tabular}{|c|c|c|c|c|c|c|}
\hline \multirow{2}{*}{$\begin{array}{l}\text { Land-use/land } \\
\text {-cover classes }\end{array}$} & \multicolumn{2}{|l|}{2008} & \multicolumn{2}{|l|}{2014} & \multicolumn{2}{|l|}{2017} \\
\hline & $\begin{array}{l}\text { AREA } \\
(\mathrm{Ha})\end{array}$ & $\begin{array}{l}\text { Area } \\
(\%)\end{array}$ & $\begin{array}{l}\text { AREA } \\
(\mathrm{Ha})\end{array}$ & $\begin{array}{l}\text { Area } \\
(\%)\end{array}$ & $\begin{array}{l}\text { AREA } \\
(\mathrm{Ha})\end{array}$ & $\begin{array}{l}\text { Area } \\
(\%)\end{array}$ \\
\hline Wasteland & 244.28 & 28.89 & 329.50 & 38.96 & 341.02 & 40.33 \\
\hline Built-up land & 3.89 & 0.46 & 4.63 & 0.54 & 5.31 & 0.62 \\
\hline Agricultural land & 597.34 & 70.64 & 369.13 & 43.65 & 352.53 & 41.68 \\
\hline Water body & - & - & 103.75 & 12.75 & 147.04 & 17.39 \\
\hline Total area & 845.53 & & 845.53 & & 845.53 & \\
\hline
\end{tabular}

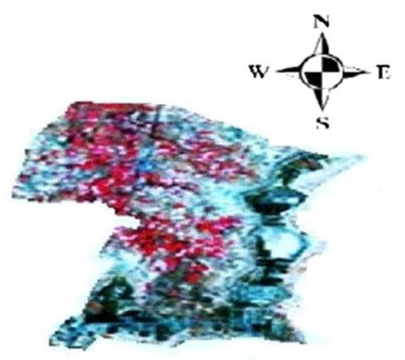

(B) 2014
(A) 2008

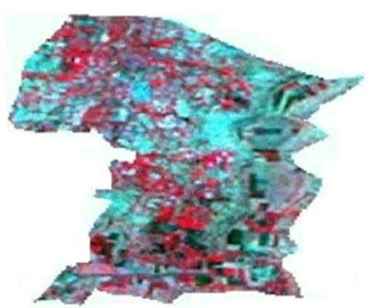

were based on the ratio among both bands that are extremely delicate to the green biomass; it is demarcated as.

$\mathrm{NDVI}=(\mathrm{NIR}-\mathrm{R}) /(\mathrm{NIR}+\mathrm{R})$

NIR is the near-infrared band, and $\mathrm{R}$ is the red band. For LISS-III 4 and 2, the NIR and R bands are 4 and 2, respectively, whereas, for Landsat 8 the NIR and R bands are 7 and 4. During the calculation of the NDVI values, the output is shown on greyscale raster map with index ranging from 1 to -1 . As per requirements, we can change the colours in NDVI map.

\section{Change detection}

Land-use change detection and analysis maps were done by using the supervised classification technique and ArcGIS 10.3 Software. Various satellite image classification is mostly measured by pixels and spectral reflectance of features. These techniques were totally depended on pixels or grids within particular class. The basic concept accepted these chances, which are equivalent to various input bands. However, these techniques required a so-long period for calculation, depending seriously on a regular classification of the data in every input band to over-categorize signatures with comparatively big values of the covariance matrix (Rosenfield and Fitzpatirck-Lins1986; Riebsame et al. 1994; Ruiz-Luna and Berlanga-Robles 2003; Owojori and Xie 2005; Yuan et al. 2005). The smallest estimation period for supervised classification technique is required. This study's effective error matrix and Kappa coefficient techniques have helped to the evaluation of land-use maps, and the accuracy of results was estimated. Therefore, five land-use and landcover classes such as agricultural land, wasteland, built-up land, and water body were found in respective years. The assessment of land-use and land-cover map methodology is presented in Fig. 3. 


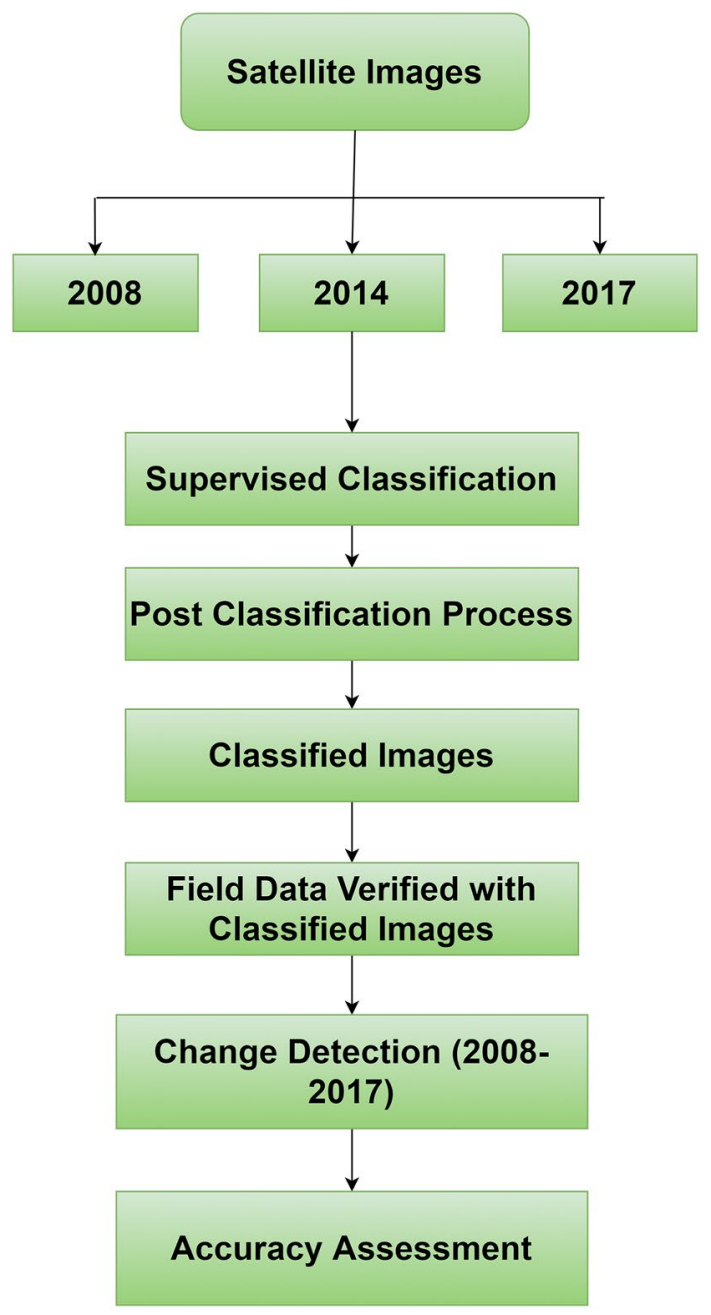

Fig. 3 Flow chart of the methodology

\section{Results and discussions}

The final classified land-use maps are shown in Fig. 4a, b and c. Table 4 shows the change matrix for varying areas from one class to another class in between the assigned dates. Moreover, the whole area of land use and land cover was shown in the hectare unit, and fraction of every land-use and land-cover class between various periods is shown in Table 2. The outcome of a supervised classification method discloses general decreases in agricultural land and an increase in waste, built-up, and water body land during the years of 2008, 2014, and 2017. The results of study area have been showed agricultural land changes of land use and land cover in the watershed area (597.34 Ha (70.64\%)), (369.13 Ha (43.65\%) (352.53 Ha (41.68)) during years of 2008, 2014, and 2017, respectively. The wasteland, representing the agriculture land, is converted to wasteland in the watershed area (244.28 Ha (28.89\%)), (329.50 Ha (38.96\%)), (341.02 Ha (40.33)) for 2008, 2014, and 2017, respectively. These areas are insufficient rainfall, and drought condition issues directly affected on the agriculture crops and landuse classes in the area. The remaining two land-use classes (built-up and water body) are denoted as (3.89 Ha (0.46\%)), $(4.63 \mathrm{Ha}(0.54 \%))(5.31 \mathrm{Ha}(0.62 \%))$ and $(0 \mathrm{Ha}(0 \%))$, $(103.75 \mathrm{Ha}(12.75 \%))(147.04 \mathrm{Ha}(17.39 \%))$ in the years of 2008,2014 , and 2017 , respectively. The water body area is increased by $12.75 \%$ and $4.64 \%$ in 2008 and 2014 years and 2014 and 2017 years mostly increased due to soil and water conservation activities during five projects. The builtup land areas are 0.08 and $1.42 \%$ increase due to the population growth in 2008 and 2014 and 2014 and 2017 (Table 2).

\section{Accuracy valuation for the classified images}

Therefore, two kinds of correctness were studied in the confusion matrix user and producer accuracies (Table 3). Based on those kinds of classification, the total image classification correctness and overall kappa statistics were measured. While the whole classification accurateness for the separated images is $>85 \%$ depended, Anderson et al. 1976 proved that the satisfactory accurateness of sorting should be $>90 \%$ and kappa statistics $>0.9$. The accurateness calculation of the different land-use maps produced was verified by using classifiers. It has executed depending on the calculation of the error matrix statistics (Pande et al. 2018). As per the outcome, the land-use maps measured different accuracy methods such as overall accuracy (OA), user's accuracy (UA), producer's accuracy (PA), and the kappa coefficient $(\mathrm{Kc})$, which are measured by Eqs. 1, 2 and 3 .

User's accuracy : $A_{u}=P_{i i} / P_{i+}$.

Producer accuracy : $A_{P}=P_{i i} / P_{+1}$.

Overall accuracy $=A_{o}=\frac{\sum_{i=1}^{m} P_{i i}}{n} \times 100$.

\section{Supervised classification maps}

In this paper, past satisfactory accurateness of three thematic maps of land use and land cover based on the supervised classification method is agreed. The results of produced overall accuracies of 97.54, 95.54, and 

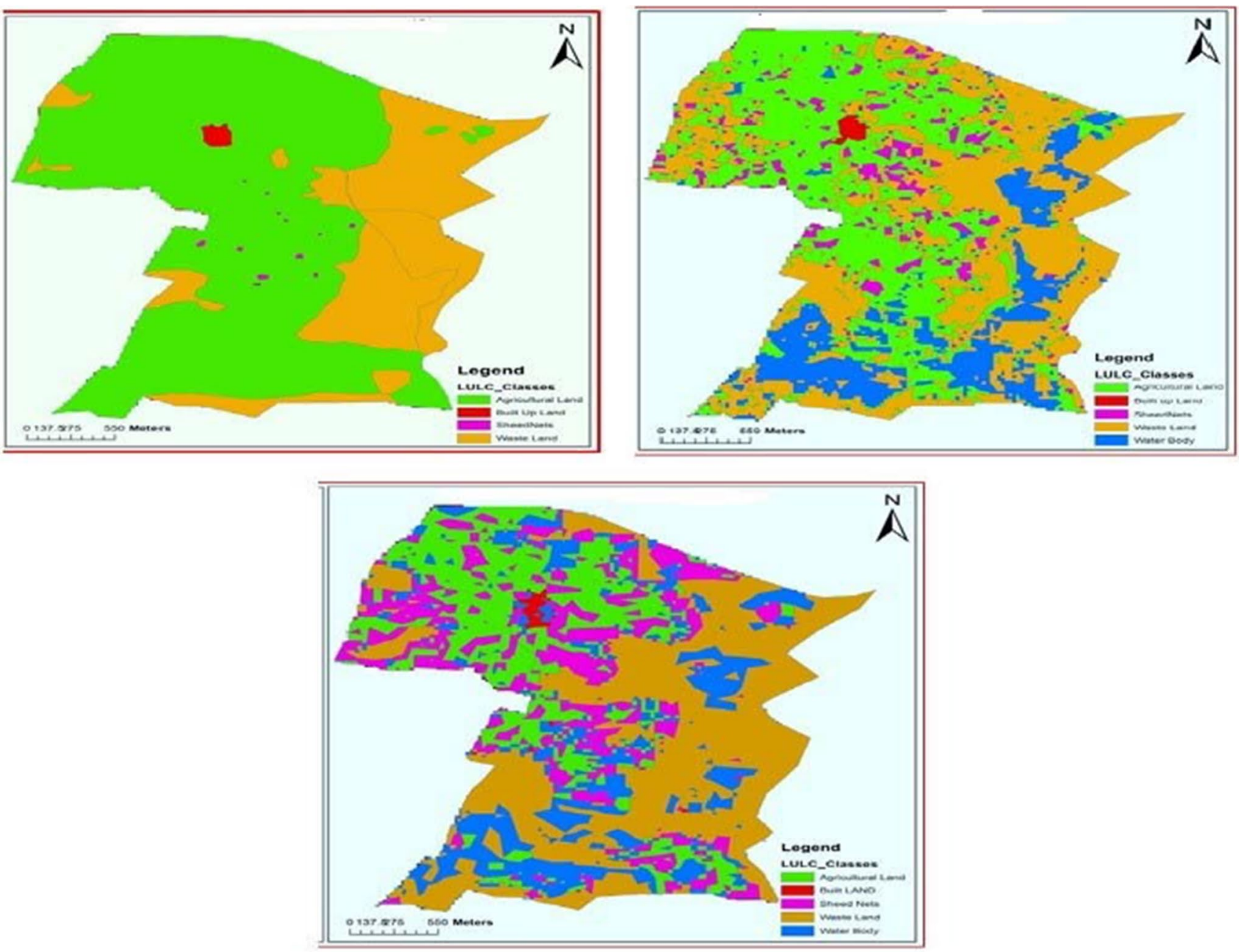

Fig. 4 The classified maps for land-use/land-cover classes (a) 2008, (b) 2014, (c) 2017

Table 3 Matrices error for 2008, 2014, and 2017 classified images depends on the supervised classification method of the study area

\begin{tabular}{|c|c|c|c|c|c|c|c|c|c|}
\hline \multirow[t]{3}{*}{ Land-use classes } & \multicolumn{9}{|l|}{ Years } \\
\hline & \multicolumn{3}{|c|}{ Producer's accuracy $(\%)$} & \multicolumn{3}{|c|}{ User's accuracy (\%) } & \multicolumn{3}{|c|}{ Kappa coefficient (\%) } \\
\hline & 2008 & 2014 & 2017 & 2008 & 2014 & 2017 & 2008 & 2014 & 2017 \\
\hline $\begin{array}{l}\text { Agricultural } \\
\text { land }\end{array}$ & 90.23 & 91.67 & 93.87 & 92.54 & 94 & 95 & 0.78 & 0.73 & 0.79 \\
\hline $\begin{array}{l}\text { Waste } \\
\text { land }\end{array}$ & 94.50 & 95 & 97 & 93 & 94 & 96 & 0.89 & 0.87 & 0.85 \\
\hline $\begin{array}{l}\text { Built-up } \\
\text { land }\end{array}$ & 100 & 100 & 100 & 100 & 100 & 100 & 100 & 100 & 100 \\
\hline $\begin{array}{l}\text { Water } \\
\text { body }\end{array}$ & 100 & 100 & 100 & 100 & 100 & 100 & 100 & 100 & 100 \\
\hline $\begin{array}{l}\text { Overall classification } \\
\text { Accuracy }\end{array}$ & 97.54 & 95.54 & 93.54 & & & & & & \\
\hline $\begin{array}{l}\text { Overall kappa } \\
\text { Statistics }\end{array}$ & 94.32 & 96.32 & 97.32 & & & & & & \\
\hline
\end{tabular}


$93.54 \%$ during the years of 2008,2014 , and 2017 classified the imageries, respectively; overall, the kappa statistics were $>0.90$. The minimum producer accuracy of $90.23 \%$ was given to the agriculture land, while the other two land-use and land-cover classes (built-up and water body) had correctness of $100 \%$ in 2008 year. The user accuracy results have been indicated for the agricultural land in 2008, 2014, and 2017, which was $92.54 \%, 94 \%$, and $95 \%$ associated with the built-up and waterbody landuse classes, which had correctness of $100 \%$ (Table 3). The user accuracy of wasteland was $93 \%, 94 \%$, and $96 \%$ in the years of 2008, 2017, and 2017, respectively. The inspected accuracy for the 2014 classified imageries (Table 3) had almost the same trend as the 2008 classified image with a good determination of agriculture class as the producer accuracy increased to $91.67 \%$, whereas the accuracy of other classes little increased to an average of $97.54 \%$. In this study, results show that user accuracy for builtup and waterbody class's accuracy was $100 \%$, but two classes were changed in the years of 2008, 2014, and 2017, respectively. The agricultural and wasteland were better in all divided data with an accuracy of $95 \%$ and $96 \%$ during the years of 2017, but the user accuracy of agriculture and wasteland decreased to $92.54 \%$ and $93 \%$ in the year
Fig. 5 Change detection map between 2008, 2014, and 2017

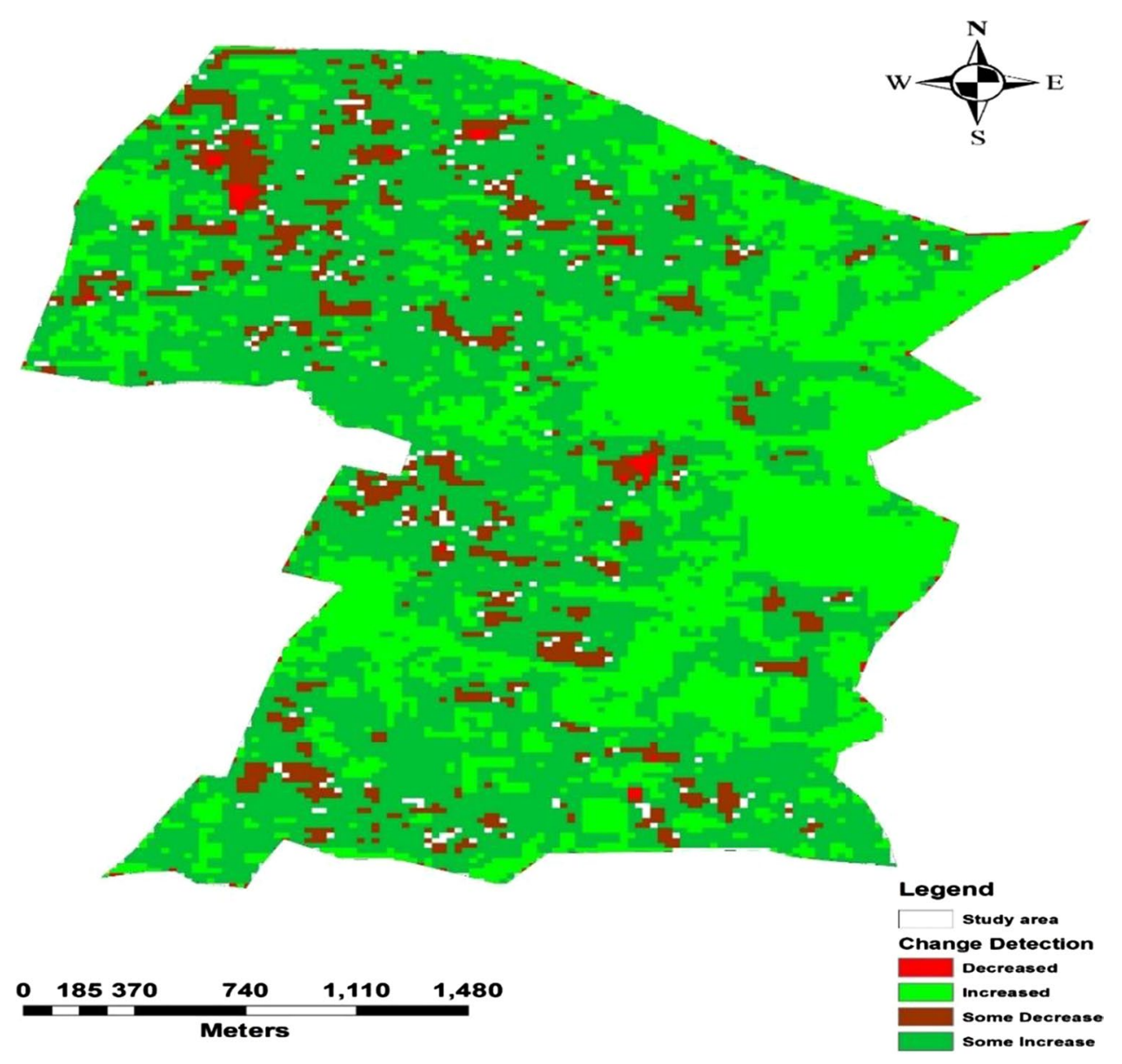

Table 4 Details of LULC change detection during 2008-2014, 2008-2017, and 2014-2017

\begin{tabular}{lccrrrrrrr}
\hline LULC & $2008(\mathrm{Ha})$ & $2014(\mathrm{Ha})$ & Changes & 2008(Ha) & 2017(Ha) & Changes & 2014(Ha) & 2017(Ha) & Changes \\
\hline Wasteland & 244.28 & 329.5 & 85.22 & 244.28 & 341.02 & 96.74 & 329.5 & 341.02 & 12.02 \\
Built-up land & 3.89 & 4.63 & 0.74 & 3.89 & 5.31 & 1.42 & 4.63 & 5.31 & 0.68 \\
Agricultural land & 597.34 & 369.13 & -228.21 & 597.34 & 352.53 & 243.81 & 369.13 & 352.53 & 16.6 \\
Water body & - & 103.75 & 103.75 & - & 147.04 & 147.04 & 103.75 & 147.04 & 43.29 \\
\hline
\end{tabular}


Fig. 6 Normalized difference vegetation index (NDVI) of 2008

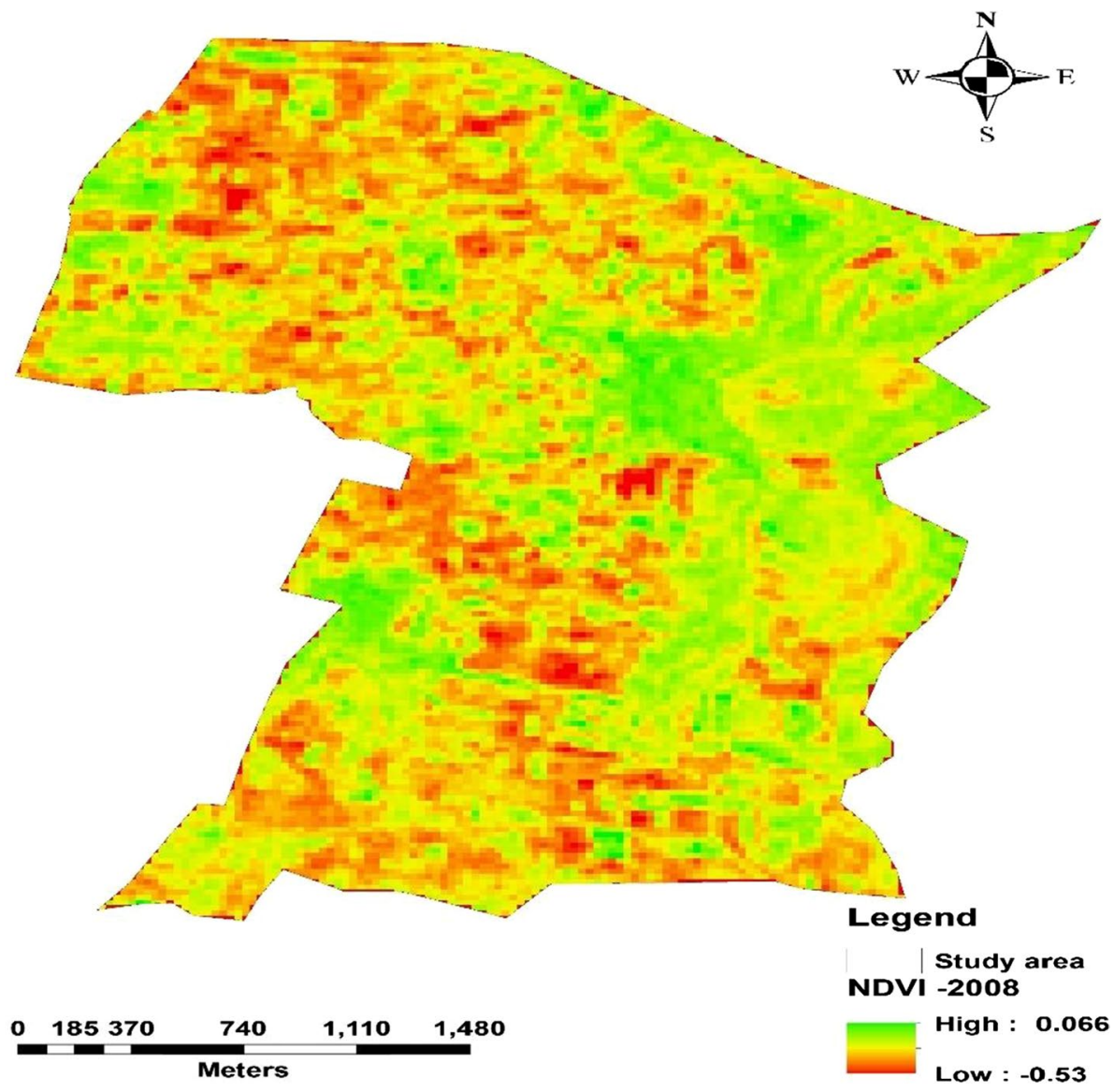

of 2008. The 2008 classified image accuracy evaluation (Table 3 ) shows various classes than the aforesaid divided images as agriculture land-finding producer accuracy was the lowest $(90.23 \%)$ with an important improvement in the built-up and water body identification (accuracy $=100 \%$ ).

\section{LULC/Change detection}

The study of monitoring the land use and land cover over 9 years (from 2008 to 2017) is concluded; the divided images indicated were employed to identify the variation in the land use and land cover for three time series 2008-2014, 2008-2017, and 2014-2017 (Fig. 5). The change matrix of the land-cover classes in between the allocated time series with the variation area by hectare and percentage is shown in Tables 2 and 4 for supervised classification, respectively.

In this study, three NDVI thematic maps were prepared during years of 2008, 2014, and 2017 in colour scale values between 1 to -1 (Figs. 6, 7 and 8). The NDVI values $>0$ denoted the wasteland, whereas the negative values and the values near about 0 are mostly made from the water body, built land, and bare soil (ESRI, 2019). The NDVI values are indicated to more healthy vegetation. Results have shown that the NDVI values ranged between $-0.53 \mathrm{t}$ o 0.066 , -0.35 to 0.11 , and -0.53 to -0.66 for 2008,2014 , and 2017, respectively. The NDVI maps are more role in the identification of classes of land use during the years of 2008, 2014, and 2017.

\section{Conclusion}

Remote sensing and GIS technologies were integrated for analysis and changes in the land-use and land-cover classes (Fig. 9). In this study, supervised classification method was used for identification of land-use classes with 
Fig. 7 Normalized difference vegetation index (NDVI) of 2014

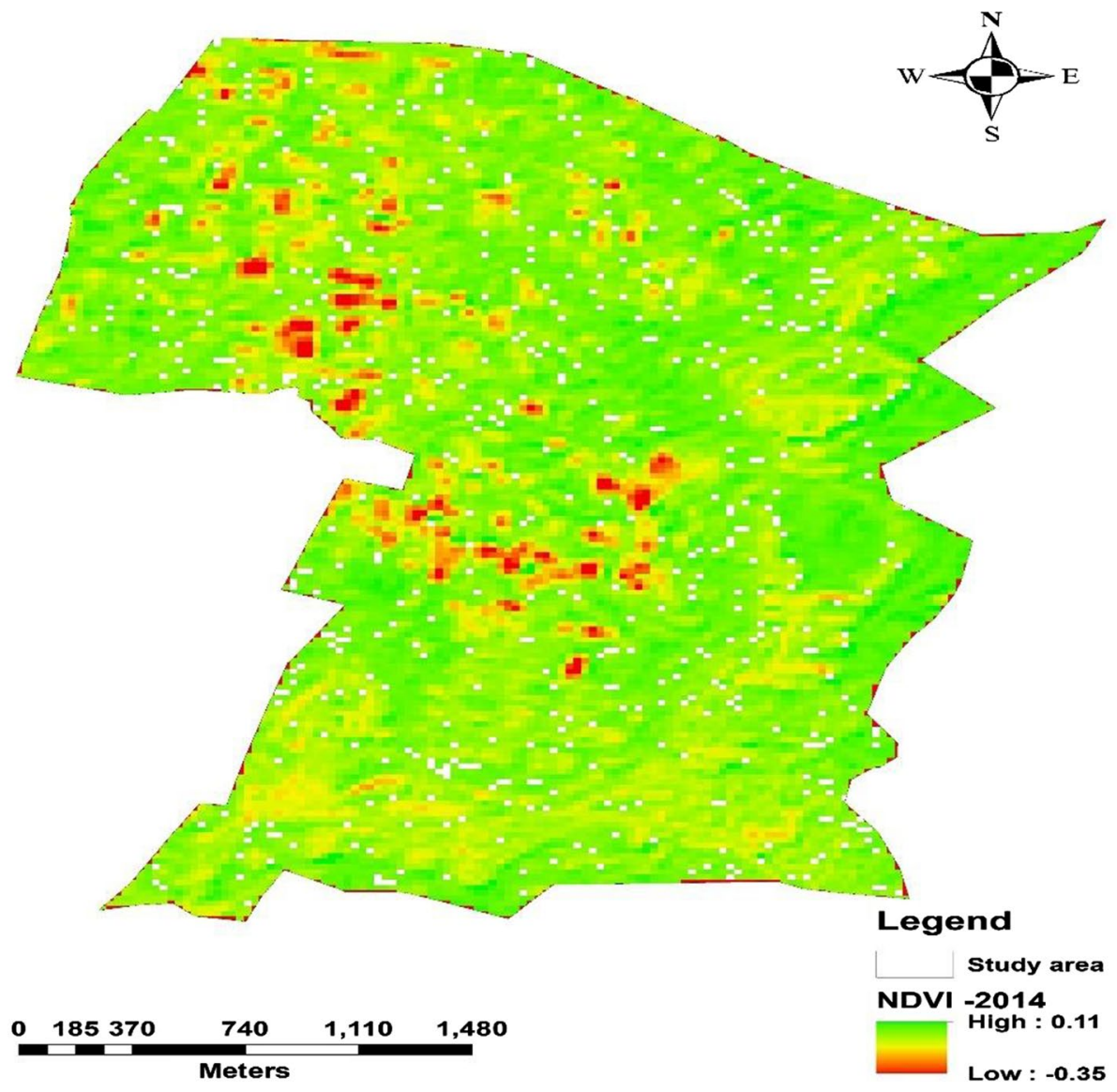

the help reference of field data. Two common classification methods (MLC and NDVI) were applied in this study. The NDVI maps were utilized to be found of vegetation conditions in the research. These maps were observed that the agriculture land shows the variation of $(597.34 \mathrm{Ha}$ $(70.64 \%)),(369.13 \mathrm{Ha}(43.65 \%))(352.53 \mathrm{Ha}(41.68))$ in area. The results of NDVI maps show vegetation analysis ranged in between -0.53 to $0.066,-0.35$ to 0.11 , and -0.53 to -0.66 for 2008,2014 , and 2017 , respectively. However, the supervised classification method has confirmed to be a good classifier because the overall accuracy is up to $95 \%$. The selected study area is under a rural area so the agricultural land is the main economic source for livelihood. The results of the study area are that it is very useful for the sector of agriculture development and increasing agronomic crops. According to the study, it is also found that the built-up land is increasing due to the human population and as compared to this agriculture land decreased due to environmental factors and human being activities. The present study thus shows that remote sensing and GIS are advanced tools for analysing and quantifying spatial necessary qualifications that traditional mapping technologies cannot otherwise be used. These technologies allow change detection in much less time, at a cheaper cost, and with greater accuracy. Further research is required to examine the water source and supply in the study area and to link the agriculture and drinking water demands with the period to provide a general environmental view of the study area. 
Fig. 8 Normalized difference vegetation index (NDVI) of 2017

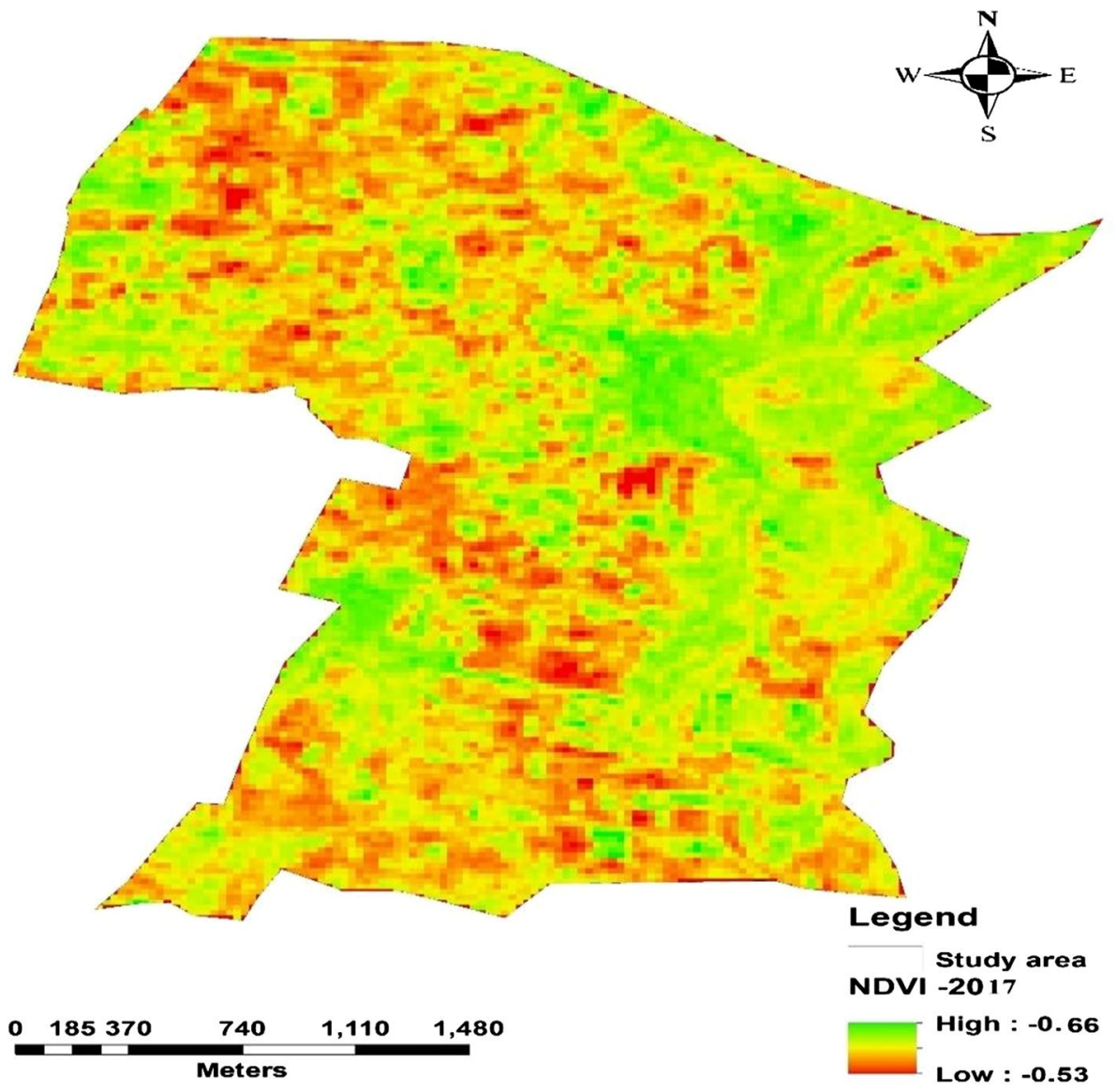

\section{Recommendations}

This study result can be very much useful for preparation of land-use policy and watershed development project. In the semiarid regions, these types of results can be helpful for understanding the drought conditions and water scarcity.

Funding No funding support to any agency.

We are not used any text form in the already published article and also no any journal submission of paper.

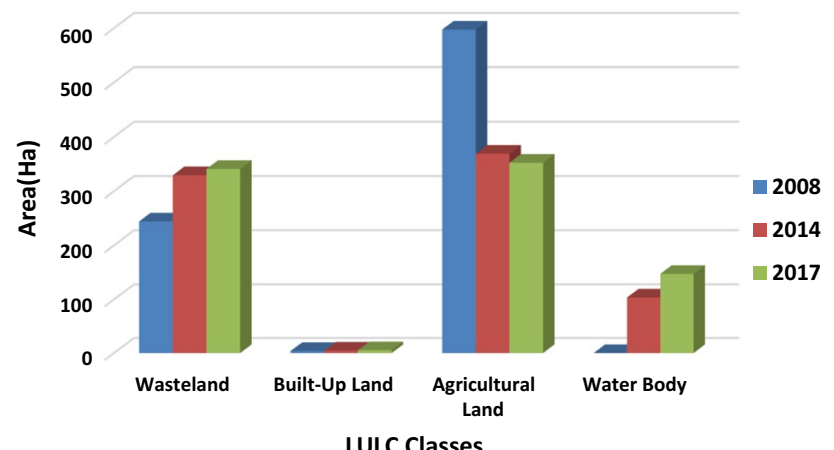

Fig. 9 Summary of land-use and land-cover classes in 2008, 2014, and 2017

\section{Declarations}

Conflict of interest There is no conflict of interest in this paper.

Ethical conduct No ethical text is used in this paper.

Open Access This article is licensed under a Creative Commons Attribution 4.0 International License, which permits use, sharing, adaptation, distribution and reproduction in any medium or format, as long as you give appropriate credit to the original author(s) and the source, provide a link to the Creative Commons licence, and indicate if changes were made. The images or other third party material in this article are included in the article's Creative Commons licence, unless indicated otherwise in a credit line to the material. If material is not included in 
the article's Creative Commons licence and your intended use is not permitted by statutory regulation or exceeds the permitted use, you will need to obtain permission directly from the copyright holder. To view a copy of this licence, visit http://creativecommons.org/licenses/by/4.0/.

\section{References}

Ahmad A, Quegan S (2012) Analysis of maximum likelihood classification on multispectral data. Appl Math Sci 6:6425-6436

Allam M, Bakr N, Elbably W (2018) Multi-temporal assessment of land use/land cover change in arid region based on landsat satellite imagery: case study in Fayoum Region Egypt. Remote Sens Appl Soc Environ. https://doi.org/10.1016/j.rsase.2019.02.002

Anderson JR, Hardy EE, Roach JT, Witmer RE, (1976) A land use and land cover classification system for use with remote sensor data. U.S. Geological Survey, Washington, DC. No. Professional Paper 964

Aydinoglu AC, Gungor O (2010) A novel land cover/use data model for GIS and remote sensing applications in Turkey. Italian J Remote Sens 42(2):27-41

Bakr N, Weindorf DC, Bahnassy MH, Marei SM, El-Badawi MM (2010) Monitoring land cover changes in a newly reclaimed area of Egypt using multi-temporal Landsat data. Appl Geogr 30:592-605

Basnyat P, Teeter L, Flynn K, Lockaby B (1999) Relationships between landscape characteristics and nonpoint source pollution inputs to coastal estuaries. Environ Manag 23(4):539-549

Brondizio ES, Moran EF, Wu Y (1994) Land use change in the the Amazon estuary: patterns of Caboclo settlement and landscape management. Hum Ecol 22(3):249-278

Caselles V, Lopez Garcia MJ (1989) An alternative simple approach to estimate atmospheric correction in multitemporal studies. Int J Remote Sens. https://doi.org/10.1080/01431168908903951

Ceccarelli T, Smiraglia D, Bajocco S, Rinaldo S, Angelis AD, Salvati L, Perini L (2014) Land cover data from Landsat single-date imagery: an approach integrating pixel-based and object-based classifiers. Eur J Remote Sens 46:699-717. https://doi.org/10. 5721/EuJRS20134641

Chan JCW, Kwok-Plng C, Yeh AG (2001) Detecting the nature of change in an urban environment, A comparison of machine learning algorithms. Photogramm Eng Remote Sens 67(2):213-225

Chander G, Markham BL, Helder DL (2009) Summary of current radiometric calibration coefficients for Landsat MSS, TM, ETM+, and EO-1 ALI sensors. Remote Sens Environ 113(5):893-903

Chapin FS, Zavaleta ES, Eviner VT, Naylor RL, Vitousek PM, Reynolds HL, Hooper DU, Lavorel S, Sala OE, Hobbie SE, Mack MC, Diaz S (2000) Consequences of changing biodiversity. Nature 405(6783):234-242

Chilar J (2000) Land covers mapping of large areas from satellites status and research priorities. Int J Remote Sens 21:1093-1114

Coppin P, Jonckheere I, Nackaerts K, Muys B, Lambin E (2004) Digital change detection methods in ecosystem monitoring: a review. Int J Remote Sens 25(9):1565-1596

Donnay JP, Barnsley MJ, Longley PA (2001) Remote sensing and urban analysis. Taylor and Francis, London and New York

El Bastawesy M (2014) Hydrological Scenarios of the renaissance dam in Ethiopia and its hydro-environmental impact on the Nile Downstream. J Hydrol Eng 20:7

Fichera RC, Modica G, Pollino M (2012) Land Cover classification and change-detection analysis using multi-temporal remote sensed imagery and landscape metrics. Eur J Remote Sens 45:1-18

Hassan RMA (2015) Ecosystem restoration using maintenance dredging in Lake Qarun. Egypt J Am Sci 11(12):55-65
Hua AK (2017) Land use land cover changes in detection of water quality: a study based on remote sensing and multivariate statistics. J Environ Public Health 2017:1-12

Iqbal MF, Khan IA (2014) Spatiotemporal land use land cover change analysis and erosion risk mapping of Azad Jammu and Kashmir, Pakistan. Egypt J Remote Sens Space Sci 17:209-229

Jensen JR (2005) Introductory digital image processing: a remote sensing perspective (third edition). Pearson prentice hall series in geographic information science. Pearson Prentice Hall, Upper Saddle River, NJ, pp 373-374

Kachhwala TS (1985) Temporal monitoring of forest land for changedetection and forest cover mapping through satellite remote sensing. In: Proceedings of the 6th asianconference on remote sensing. National Remote Sensing Agency, Hyderabad, pp 77-83

Lo CP, Choi J (2004) A hybrid approach to urban land use/cover mapping using Landsat 7 enhanced thematic mapper plus (ETM+)images. Int J Remote Sens 25(14):2687-2700

Lu D, Mausel P, Brondizio E, Moran E (2004) Change detection techniques. Int J Remote Sens 25(12):2365-2401

Mishra PK (2017) Assessment of run-off and soil loss under different land-use practices in a Himalayan Watershed, India. Am Res J Humanit Soc Sci 3:1-10. https://doi.org/10.21694/2378-7031. 17002

MishraRai PKA, Raj SC (2020) Land use and land cover change detection using geospatial techniques in Sikkim Himalaya, India. Egypt J Remote Sens Space Sci 23(2):133-143. https:// doi.org/10.1016/j.ejrs.2019.02.001

Mohammady M, Moradi HR, Zeinivand H, Temme A (2015) A comparison of supervised, unsupervised and synthetic land use classification methods in the north of Iran. Int J Environ Sci Technol 12(5):1515-1526

Moscrip AL, Montgomery DR (1997) Urbanization flood, frequency and salmon abundance in Puget Lowland Streams. J Am Water Resour Assoc 33(6):1289-1297

Osborne LL, Wiley MJ (1988) Empirical relationship between landuse-cover and stream water quality an agricultural Watershed. J Environ Manag 26:9-27

Owojori A, Xie H (2005) Landsat image-based LULC changes of San Antonio, texas using advanced atmospheric correction and object-oriented image analysis approaches. Paper presented at the 5th international symposium on remote sensing of urban areas, Tempe, AZ

Pande (2014) Change detection in land use / land cover in akola taluka using remote sensing and GIS technique. Int J Res (IJR) 1(8):1-13

Pande (2020a) Thematic mapping for watershed development. In: Sustainable watershed development. SpringerBriefs in water science and technology. Springer, Cham. https://doi.org/10.1007/ 978-3-030-47244-3-3

Pande (2020b) Sustainable Watershed Development Planning. In: Sustainable Watershed Development. SpringerBriefs in Water Science and Technology. Springer, Cham. https://doi.org/10.1007/ 978-3-030-47244-3-4

Pande C, Moharir KN (2014) Analysis of land use/land cover changes using remote sensing data and GIS techniques of Patur Taluka Maharashtra, India. Int J Pure Appl Res Eng Technol 2(12):85-92

Pande CB, Moharir KN, Khadri SFR, Patil S (2018) Study of land use classification in an arid region using multispectral satellite images. Appl Water Sci 8:123. https://doi.org/10.1007/s13201-018-0764-0

Prasad G, Vinod PG, Shaleena EJ (2018) AIP conference proceedings, international conference on electrical, electronics, materials and applied science. vol 1952(1), pp. 20-28. https://doi.org/10.1063/1. 5031990.

Riebsame WE, Meyer WB, Turner BL (1994) Modeling land-use and cover as part of a global environmental change. Clim Change 28:45-64 
Rogan J, Chen D (2004) Remote sensing technology for mapping and monitoring land-cover and land-use change. Prog Plan 61(4):301-325

Rosenfield GH, Fitzpatirck-Lins K (1986) A coefficient of agreement as a measure of thematic classification accuracy. Photogramm Eng Remote Sens 52(2):223-227

Roth NE, Allan JD, Ericson DE (1996) Landscape influences on stream biotic integrity assessed at multiple spatial scales. Landsc Ecol 11(3):141-156

Ruiz-Luna A, Berlanga-Robles CA (2003) Land use, land cover changes and coastal lagoon surface reduction associated with urban growth in northwest Mexico. Land Ecol 18:159-171

Selcuk R, Nisanci R, Uzun B, Yalcin A, Inan H, Yomralioglu T (2003) Monitoring land-use changes by GIS and remote sensing techniques: the case study of Trabzon. In:Proceedings of 2nd FIG Regional Conference, Morocco, 2-5, 1-11

Suresh G, Ramasamy V, Meenakshisundaram V, Venkatachalapahty R, Ponnusamy V (2011) Influence of mineralogical and heavy metal composition on natural radionuclide concentrations in the river sediments. Appl Radiat Isot 69:1466-1474
Verburg PH, Schot P, Dijst M, Veldkamp A (2004) Land use change modelling: current practice and research priorities. GeoJournal 61(2004):309-324

Vijith H, Satheesh R (2007) Geographical information system based assessment of spatiotemporal characteristics of groundwater quality of upland sub-Watersheds of Meenachil River, parts of western ghats, Kottayam district, Kerala, India. Environ Geol 53:1-9

Yuan F, Sawaya KE, Loeffelholz B, Bauer ME (2005) Landcover classification and change analysis of the Twin Cities (Minnesota) Metropolitan Area by multitemporal Landsat remote sensing. Remote Sens Environ 98:317-328

Publisher's Note Springer Nature remains neutral with regard to jurisdictional claims in published maps and institutional affiliations. 